УДК 130.2

DOI: $10.26565 / 2306-6687-2020-61-07$

\author{
Ikeke Mark Omorovie \\ Ph.D. in Philosophy, Associate Professor of the \\ Department of Religious Studies and Philosophy \\ Delta State University \\ 1, P.M.B., Abraka, Nigeria \\ E-mail: Ikeke7@yahoo.com \\ ORCID: https://orcid.org/0000-0001-9115-378X
}

\title{
IMPLICATIONS OF THE CONCEPT OF THE “COMMON GOOD” FOR POLITICAL LEADERSHIP
}

Political society is established for the provision of the good life for the citizens of the society. But to ensure that the task is carried out, political societies elect or appoint leaders saddled with the responsibility of guiding, directing, leading and organizing the society. Capable and efficient political leaders help their societies to develop economically and help the citizens to have access to the good life. They are concerned about the common good of the society. Inept and inefficient leaders often are concerned about their own selfish interests and bring miseries and suffering to their peoples. In spite of the ideals of good leadership and the positive values of working for the public interest and common good of their societies, there are still many political leaders who are in power for their own sakes. Because of this there are many underdeveloped and poor societies especially in the Global South. This paper uses a critical analytic and hermeneutic method to examine and appraise the concept of the common good and its implications for political leaders. The value of the common good is applicable to every society. Political leaders everywhere are to strive for the common good. The paper finds that bad and corrupt political leaders are still prevalent in many societies in the world. The presented research will also help to designate the feature of the articulation of «common good» in the modern philosophical conceptions. The paper concludes that there is need to highlight the value of the common good that political leaders should strive for and help their societies obtain. This done there will be a higher level of peace and harmonies in political societies.

Keywords: Common Good, politics, leaders, and political leadership.

\section{Ікеке Марк Оморові}

доктор філософії, доцент кафедри

релігієзнавства та філософії

Університет Дельти, 1, П.М.Б., м. Ейбраке, Нігерія

E-mail: Ikeke7@yahoo.com

ORCID: https://orcid.org/0000-0001-9115-378X

\section{ІМПЛІКАЦІї КОНЦЕПТУ «ЗАГАЛЬНЕ БЛАГО» ДЛЯ ПОЛІТИЧНОГО ЛІДЕРСТВА}

Політична спільнота створюється задля забезпечення кращого життя громадян. Для забезпечення виконання цього завдання політичні спільноти обирають або призначають лідерів, на яких покладають відповідальність за керівництво та організацію суспільних процесів. Ефективні політичні лідери допомагають своїм спільнотам розвиватися економічно та допомагають громадянам покращувати рівень життя. Вони стурбовані загальним благом суспільства. Невмілі та неефективні лідери часто турбуються про власні егоїстичні інтереси та приносять нещастя і

страждання своїм народам. Незважаючи на ідеали гарного керівництва та позитивні цінності праці задля інтересів суспільства та загального блага спільноти, все жє багато політичних лідерів, для яких важлива лише влада. Через це

(C) Ikeke M. O., 2020 
існує багато нерозвинених і бідних суспільств, особливо на Глобальному Півдні. У цій роботі використовуються критичний, аналітичний та герменевтичний методи для вивчення та оцінки концепції загального блага та ії значення для політичних лідерів. Розглядається контекст філософського осмислення загального блага від Платона і Аристотеля до Д. Локка і Ж.-Ж. Руссо. Цінність загального блага застосовується для кожного суспільства. Політичні лідери скрізь мають прагнути до загального блага. У статті продемонстровано, що неефективні та корумповані політичні лідери досі переважають у багатьох суспільствах світу. У статті робиться висновок про необхідність акцентувати цінність загального блага, на яку повинні орієнтуватися політичні лідери, що допоможе досягти вищого рівня миру та злагоди у політичних суспільствах.

Ключові слова: загальне благо, політика, лідери та політичне керівництво.

\author{
Ікеке Марк Оморови \\ доктор философии, доцент кафедры \\ религиоведения и философии \\ Университет Дельты, \\ 1, П.М.Б., м. Эйбраке, Нигерия \\ E-mail: Ikeke7@yahoo.com \\ ORCID: https://orcid.org/0000-0001-9115-378X
}

\title{
ИМПЛИКАЦИИ КОНЦЕПТА «ОБЩЕЕ БЛАГО» ДЛЯ ПОЛИТИЧЕСКОГО ЛИДЕРСТВА
}

Политическое сообщество создается для обеспечения лучшей жизни граждан. Для реализации этого задания политические сообщества выбирают или назначают лидеров, на которых возлагают ответственность за руководство и организацию общественных процессов. Эффективные политические лидеры помогают своим обществам развиваться экономически и помогают гражданам улучшать уровень жизни. Они обеспокоены общим благом общества. Неумелые и неэффективные лидеры часто беспокоятся исключительно о своих эгоистических интересах и приносят несчастье и страдание свои народам. Несмотря на идеалы хорошего руководства и позитивные ценности труда для интересов общества и общего блага сообщества, все же есть много политических лидеров, для которых важна лишь власть. Из-за этого существует много неразвитых и бедных обществ, особенно на Глобальном Юге. В этой работе используется критический, аналитический и герменевтический методы для изучения и оценки концепции общего блага и ее значения для политических лидеров. Рассматривается контекст философского осмысления общего блага от Платона и Аристотеля до Д. Локка и Ж.-Ж. Руссо. Ценность общего блага применяется к каждому обществу. Политические лидеры повсюду должны стремиться к общественному благу. В статье продемонстрировано, что неэффективные и коррумпированные политические лидеры до сих пор преобладают во многих обществах мира. В статье делается вывод про необходимость акцентировать ценность общего блага, на которую должны ориентироваться политические лидеры, что поможет достичь более высокого уровня мира и согласия в политических сообществах.

Ключевые слова: общее благо, политика, лидеры и политическое руководство.

\section{Introduction.}

Effective and good political leadership is vital for the development and upward progress of every society and state. Leadership could in many cases be considered "the most important element for order and progress in any human undertaking. It is extremely vital and in fact, central to the control, motivation, and direction of every human society towards development, progress and meaningful achievement in all human affairs, whether social, economic or political, both of domestic or national" [Adefarasin, 2015, p. 731]. Political societies are set up for the provision of the good and abundant life for the members of the society. In order that this should be 
accomplished political leaders are put in place to direct and guide the society in the attainment of the good of the entire society. When political leaders are inept and weak it becomes difficult for the political and social goals of the society to be achieved. While there are many examples of good and capable political leaders in the world there are equally many examples of corrupt and selfish leaders who instead of enabling the good life in their societies have underdeveloped their societies through their corrupt and anti-social behaviours.

Many inept and inefficient leaders are often not concerned for the common good of their societies. They are simply in power to enrich themselves and their cronies. It is vital and important then to continue to reflect on the notion of the common good as it is vital to creating flourishing human societies and political communities. This paper argues that political leaders exist to foster the common good of the political society and not to corruptively enrich themselves or foster their personal good to the detriment of the political society. The paper therefore will hermeneutically analyze and interpret the concept of the common good. It will break open the notion for understanding of the issues. It will draw out the implications of the notion of the common good for political leaders and their leadership.

\section{The Concept of the Common Good}

The common good as the name implies is common to all in the society. It is what benefits all in a society in opposition to the individual private good or sectional interests [Lee, 2016]. Lee states that from the time of ancient Greek society to the present day the common good is a recurring theme in western political thought that points society towards certain goods such as justice, security, and stresses the need for collective actions to obtain it [Lee, 2016]. There are various viewpoints on what constitutes the common good or how it can be obtained. An examination of few of these is necessary here. For Plato, the common good obtains when the citizens live a virtuous life in accordance with the laws of the city [Plato, 1941]. Aristotle affirms that the common good is what benefits the polis (city), and not the good of the ruler [Aristotle, 1984]. Mansbridge indicates that for Aristotle the overall meaning of the common good in the political field is what benefits all and that is justice [Mansbridge, 2013, p. 915]. It is important to remark that: "Plato and Aristotle present a vision of the common good that cannot simply be reduced to the sum of all private interests, but whose promotion is nonetheless conducive to those interests - virtuous, fulfilled citizens and harmonious communities are both consequences of the pursuit of the good life" [Etzioni, 2015, p. 1]. For the Roman Cicero, the chief law for the Roman magistrate is the good of the people. In Augustine, the common good is that human beings live as citizens of the kingdom of God and in obedience to his laws and worship him [Augustine, 1998]. Laws in the political city must be just laws following divine command. For Thomas Aquinas, God is the supreme good and humans are to rationally live in recognition of his divine order [Aquinas, 2002]. The political actors must act to promote laws that foster the good of all, not the private good.

In his days, John Locke is of the opinion that government is to serve the common good if not the people can limit or depose the government [Locke, 1998]. In Jean-Jacques Rousseau there is a radical enunciation on what constitutes the common good. Moving from a state of nature, the citizens willingly and voluntarily in the "general will" handed over their powers to political authority to act and serve on their behalf the good of the citizens [Rousseau, 1993]. And political authority is only legitimate when it serves the common good of all the citizens.

In many modern nation-states, political society is governed by constitutions and democratic values. The common good is enshrined in the constitutions of those nation-states. And the constitution is the supreme law of the land. Those in political office are to serve the people in safeguarding their human rights and providing social services. Take for instance the constitution of Nigeria which dictates that the fundamental objective of the Nigerian state is to promote democracy, social justice, security and welfare of the people [Federal Republic of Nigeria, 2011, pp. 25-26]. In the preamble of the US Constitution, it is enunciated that to establish a more perfect union, government is to work to ensure justice, tranquillity, general welfare and the prosperity of the people. The Ukrainian Parliament in the preamble of the Ukrainian constitution states that the Republic shall strive to "ensure human rights and freedoms, and life conditions worthy of human dignity" [Ukrainian Parliament, 1996, p.1]. Constitutions of various nations may state the common good in different way, but it is certainly for the overall wellbeing of the people. This paper asserts that what the constitution of a nation strives 
to achieve is the common good of the citizens of the nation. All the conditions that enhance the people obtaining justice, security, peace, tranquillity, human rights, etc are all aspects of the common good.

It imperative to note that the common good is not just an abstract concept. It has to do with practical matters in society and the way it is organized either for the welfare and wellbeing of all citizens or for the welfare of some few leaders. "The demands of the common good... concern above all the commitment to peace, the organization of the State's powers, a sound juridical system, the protection of the environment, and the provision of essential services to all, some of which are at the same time human rights: food, housing, work, education and access to culture, transportation, basic health care, the freedom of communication and expression, and the protection of religious freedom. Nor must one forget the contribution that every nation is required in duty to make towards a true worldwide cooperation for the common good of the whole of humanity and for future generations also" [Pontifical Council for Justice and Peace, 2005, p. 91].

Political society exists for the common good of the members of that society. In like vein, political leaders exist for the common good not their personal interests. In contemporary politics it is important to remark that politics should move beyond liberal economic values and the narrow interests of politicians to securing the good of all in a collective manner in which political participation is seen as an intrinsic value [Lee, 2016]. All the social conditions that help human persons to achieve their authentic goals and destiny in concert with one another constituents the common good. Overall, conceptualizing philosophically, the common good refers to members of a political community living in political or civil relationships that requires then to create and keep certain facilities they foster their common interests [Hussain, 2018].

It should be realized that the common good coincides with the public interest in most cases. The common good of the political society may vary from one society to another but the important fact is that it is for the welfare and wellbeing of the entire people not a sectional good or selfish interest of those in power. The common good is not stagnant and depends on the changing conditions of human sociality and historical situations though always it is connected to "respect for and the integral promotion of the person and his fundamental rights" [Pontifical Council for Justice and Peace, 2005, p. 91]. The point here is that the situations and conditions of human existence are not same. Human conditions can be enhanced by advances in science and technology.

\section{The Concept of and Challenge before Political Leadership}

It is important here to define political leadership. Like any other concept, the term «leadership» is difficult to define. With regard to leadership, it is perceived as "social influence" that leaves a mark, initiating and guiding people to achieve desired results [Manning and Cutis, 2003, p. 2]. A similar definition by Koontz et al enunciate that leadership is "influence, the art or process of influencing people so that they will strive willingly towards the achievement of group goals... Leaders act to help a group achieve objectives with the maximum application of its abilities" [Adesanwo, 2010, pp. 51-52]. For leadership, another viewpoint is that it "is the process through which one individual consistently exerts more influence than others in the pursuit of group behaviour" and "political leadership is the decision on the social policy and resource allocation, as exerted by partisan representatives" [Agaba and Daniel, 2010, p. 105]. Implied in this definition is that political leaders exist for the distribution and allocation of the scarce resources of the society or nation. All human beings in political society strive to meet their needs of food, water, shelter, psychological needs and others in society. In the process of this struggle there is bound to be tension and conflicts in society. Political leaders are empowered by the citizens of the society to help them achieve these needs in an amicable manner.

Leadership exists in various cycles such as in the educational institutions, religious communities, professional association, business world, etc. The concern here is with political leadership. Political leadership refers to the processes and relationships involved with those who are entrusted with political offices influencing and guiding the political society to accomplish her goals and aims. From one viewpoint, political leadership is the "bundle of attributes, including knowledge, patriotism, nationalism, vision, courage, imagination, determination, decisiveness, transparency, motivation, and will, deployed by occupants of strategic political positions to lead their citizenry towards profound transformation of social institutions" [Ukaegbu, 2010, p.16].

The term, political leadership will be used in a limited sense to imply all those who have been elected or appointed into public office in a political society for the administration and governance of that society. In general 
for instance, leaders in political parties can be called political leaders in a certain sense, but the concern in this paper is not to such persons. Political leaders include the head of states, presidents and prime ministers of nationstates, ministers and heads of government agencies and departments, mayors of cities and local governments, members of parliaments, etc. Recognize that, "Political leaders are vitally important - through the authority of government, they assess the distribution of power and resources, build relationships with other stakeholders and make decisions that can have great impact on the well-being of a nation and its people" [Cohen, 2020]. Cohen argues further that: "Leadership in the political framework requires a focus on the long-term good of a country, above and ahead of any personal short-term gains. Good political leadership requires a combination of charisma and integrity, as well as the ability to assess a situation and make a decision based on what would be best for the greatest number of people. Most of all, leadership in a political framework requires "statesmanship" - as opposed to just being a "politician" - this means having the integrity and willingness to stand up for what is right, even if it means resigning a position in government or losing an election" [Cohen, 2020].

Political leaders are to carry out the functions of government in the nation-states at various levels. For the avoidance of doubt these functions are carried out through the executive, legislative and judiciary. With regard to government, "the first and most essential function of government is the protection of its citizens and preservation of the state in which behalf it is created" [Ayeni-Akeke, 2008, p. 282]. Furthermore, government should help in "distribution of social wealth in a way that will prevent excessive inequality", create "opportunities for people to take advantage of social services such as health and education services", facilitate "social, economic and technological development through encouragement of investment and research", provide "wages and salaries for state employees" [Ayeni-Akeke, 2008, p. 286]. Political leaders are in office to help to accomplish all these. Being a political leader in government is a serious responsibility that should not be taken for granted. Through carrying the functions of government, political leaders help to foster the common good and the conditions necessary to attain the common good.

Political leaders like all other leaders should be conscientious, accountable, morally upright, and not despotic, demonstrate credibility, be selfless, be visionary, and show empathy and integrity. They should be honest, kind, and have the interest of the public good in mind. Political leaders exist to promote the political good of the society. Good political leadership is vital for the development of society and creating institutions that support the common good [Uchendu, Okpoko and Anugwom, 2010].

\section{Implications of the Common Good for Political Leadership}

The common good is the responsibility of all members of society [Pontifical Council for Justice and Peace, 2005, p. 91]. Outside the contributions of citizens in a political society to ensure that the goals of the society are achieved, a major responsibility is entrusted to the political leaders to ensure that the common good of society is propagated. In many democratic societies there are three main arms of government-the executive, the legislature, and the judiciary. Political leaders are there to carry out the functions and duties of government for the wellbeing of the people. They are appointed or elected for the good of the society and not to serve their own personal interests. The fundamental argument of this paper is that all political leaders should take into consideration the common good. They are not elected or appointed into office to serve their personal interests or sectional good.

The notion of the common good is crucial to all political leaders in the global society. They should serve the common good of their own particular societies and also the global common good. This signifies that in promoting the common good in their own particular societies, they should be mindful of moral cosmopolitan values and international law. What a particular political society considers to be common good should not violate global humanistic values. A nation or a leader that glorifies crimes against humanity, human sacrifice, racism, etc should not be tolerated. National values should not offend against the global common good. National political leaders should be in constant dialogue with other global political leaders to navigate all differences and serve the global common good.

There are tremendous benefits and results when political leaders serve the common good. The society is built-up. Peace and harmony are enhanced. When political leaders fail the consequences can be grave. Failure of political leaders has led to conflicts, violence and wars as people struggle for the resources of the country. Take 
the cases of resource rich nations such as Liberia, Sierra Leone, Democratic Republic of Congo, Namibia, Iraq, etc. They have at one time or the other been plunged into wars. Inept and corrupt leaders instead of serving the common good enrich themselves at the expense of the people. In a country like Nigeria, ethnic militant agitations are rife as a result of the failing nature of the state due to decades of corrupt leadership. Serving the common good should be the touchstone of political leadership. The crisis of ethical political leadership which this paper perceives as political leadership for the common good is responsible for underdevelopment in much of the global south [Nwozor, 2014; Arinze, 2014].

It is imperative to continuously re-echo the issue of the common good in the light of the many failures of political leadership globally. The failure of political leadership to tame anti-social forces is glare in Yemen, Afghanistan, Sudan, and South Sudan, etc. In some countries in the North Africa and the Middle East, citizens have suffered from poor and corrupt leadership for decades. Many live in abject poverty, are deprived of social infrastructures and are deprived of enjoying the good life that political society should provided. Egypt has suffered from decades of authoritarian rule. For many decades Sudan equally suffered from authoritarian rule. South Sudan has gained independence from Sudan but has been plunged into constant violence and conflicts by her political actors including political leaders. Poor leadership and governance on the path of political leaders led to the Arab Spring. The sacrificial act of setting himself on fire of Mohammed Bouazzi in December 2010 led to the authoritarian ruler Zine El Abidine Ben Ali to leave power and precipitated protests in some other Arab countries such as Egypt, Bahrain, Libya, Syria and Yemen [History Dot Com Editors, 2020]. North Korea is suffering under an autocratic regime. The point is that if the state fails very often it is essentially as a result of poor political leadership.

Compared with poor political leadership especially the kind experienced in most developing economies of the global south, many countries in the western world are experiencing good political leadership rooted in democratic values. This has led to the transformation of those societies. Good political leaders are transformational leaders. While there are some bad political leaders in western and other countries, by and large they have a harvest of many good political leaders. Some of these good leaders have helped in the rapid transformations of their societies. These societies include United States, Canada, United Kingdom, Japan, South Korea, Singapore, and many others. There are many good political leaders in these countries and they have stable social institutions that work no matter the leaders in office. This is in contrast to many post-colonial societies of the global south where government institutions are fragile and weak. The admirable story of Lee Kuan Yew of Singapore who turned a third world country into an economically and technologically advanced country in enhancing better life for the citizens is yet to be forgotten. Compare this with the poor political leadership styles of people like Robert Mugabe who turned his nation of Zimbabwe into one of the poorest nations on earth.

Political leadership that acts for the common good of society matters and makes a great difference. Many political leaders who fail to act for the common good often corruptly enrich themselves from public fund. Money that should be used for the development of social infrastructures to improve the common good is stolen and deposited in western banks. In a country like Nigeria, a former military ruler, Sani Abacha corruptly enriched himself and lodged public funds in western banks. As at this year, Nigeria is still recovering money that Abacha lodged in foreign banks. Like Nigeria, there are still many countries in the so-called third world where political leaders still continue to loot public coffers to enrich themselves. These are leaders who care little or nothing for the common good. Inclusive in the list of bad political leaders who destroyed their nations are JeanBedel Bokassa of Central African Republic, Idi Amin of Uganda, Saddam Hussein of Iraq, and Mobuto Sese Sekou of Zaire (now Democratic Republic of Congo). Much of the poverty, social disability and economic suffering that citizens in these countries with poor political leadership have experienced are rooted in the way that political power has been exercised. Political leaders who lack a concern for the common good hardly promote universal freedoms. All they think about most often is how to secure themselves in power. Take a country like Egypt for instance that has many of the potentials to be a highly developed nation economically and technologically. What has held Egypt back and kept her in the doldrums are an ineffective and corrupt state, and the misuse of political power that is monopolized by a few elites [Acemoglu and Robinson, 2013, p. 2]. What applies to Egypt applies to many other poor nation-states where political power has been abused. In a nation like Egypt and many other impoverished nations, political power is in the hands of a few elites who accumulate 
wealth for their narrow selfish interests instead of working for the common good [Acemoglu and Robinson, 2013, p. 3].

Indeed, the crucial point that this paper propounds is that political leaders have a great role to play in promoting and advancing their nations into the global frontiers of greatness. It is political leaders who exercise political leadership and power. They ought to use it to enhance the common good of society not the narrow interests of a few elites. What has happened in many of the poor countries of the world is that political leaders have used political power selfishly for the advantage of a few to the neglect of the vast majority of people. When political leaders act for the common good of their nations and in accord with international global ethical values encapsulated in various human rights documents and declaration they create better and more harmonious societies. In all of these, political leadership and power are important for economic institutions are determined by politics and political institutions [Acemoglu and Robinson, 2013, p. 43].

\section{Conclusion}

The author of this paper has examined the notion of the common good. The common good it was revealed embraces all those conditions, situations and processes that enhance the wellbeing and welfare of the citizens. The common good of society is the good life for which political societies are in place. It includes justice, peace, harmony, tranquillity, wellbeing, and eudaimonia (happiness and human flourishing). The paper revealed that political leaders are elected or appointed for the sole responsibility of acting in concert with the people to obtain the common good. They are not in office for their own personal or sectional good. Political leaders should be free from corruptions and all the negative practices that impede the good of society. When political leaders are effective, honest, transparent, decisive, statesmanlike, foresighted, and empathic and act for the common good of the society, society experiences tremendous economic and scientific advancement. This is precisely what has happened in many developed societies in the western world and some few ones in the global south where good and efficient leaders and stable governmental institutions exist. It is concluded here that political leaders should ensure they serve the common good for which they are put in office.

\section{REFERENCES}

Acemoglu, D. \& Robinson, J. A. (2013). Why Nations Fail: The Origins of Power, Prosperity and Poverty. London: Profile Books.

Adefarasin, V. O. (2015). Effective Leadership as the Basis for Nigeria's Quest for Development. In Nationalism and Economic Justice in Nigeria (pp. 730-746). (Y. K. Salami, J. O. Famakinwa \& G. Fasiku, Edit.). IleIfe, Nigeria: Obafemi Awolowo University Press.

Adesanwo, A. S. (2010). In Search of Leadership: Transformational Management of Nigeria for Year 2010 and Beyond. Lagos: A1 Investment.

Agaba, J D. \& Daniel, E. (2010). Beyond the Rhetorics of Statecraft in Africa: Search for a New Paradigm of Leadership in Nigeria. In Perspectives on Leadership in Africa (pp. 103-114). (Egodi Uchendu, Pat Uche Okpoko \& Edlyne Anugwom, Edit.). Nsukka: Afro-Orbis Publishers.

Arab Spring. (2020). Retrieved from: https://www.history.com/topics/middle-east/arab-spring.

Arinze, N. (2014). Political Leadership and State Failure in Africa: Lessons from the Central African Republic. In Politics and Law in Africa (pp. 174-187). (Aloysius-Michaels Okolie, Onyemaechi A Eke \& Paul A. Areo, Edit.). Abakaliki, Nigeria: Willy Rose \& Appleseed.

Aristotle. (1984). Politics. (C. Lord, Trans.). Chicago: University of Chicago Press.

Aquinas, Th. (2002). St Thomas Aquinas: Political Writings. (R. W. Dyson, Trans.) Cambridge: Cambridge University Press.

Augustine. (1998). The City of God against the Pagans. (R. W. Dyson, Trans.). Cambridge: Cambridge University, Press.

Ayeni-Akeke, O. A. (2008). Foundation of Political Science. Ibadan: Ababa Press. 
Cicero. (1926). De Legibus. Loeb Classical Library. (C. W. Keyes, Trans.). Cambridge: Harvard University Press.

Cohen, Hsin-Yi. (2020). A Political Leader. Retrieved from: http://www.leadershipexpert.co.uk/politicalleader.html.

Etzioni, A. (2020). Common Good. In The Encyclopedia of Political Thought (pp. 1-7). (Michael T. Gibbons, Edit.). Hoboken, N J: John Wiley and Sons. DOI:10.1002/9781118474396.wbept0178.

Federal Republic of Nigeria. (2011). 1999 Constitution of the Federal Republic of Nigeria with Amendments.

Hussain, W. (2020). The Common Good. In The Stanford Encyclopedia of Philosophy. (E. N. Zalta, Edit.). Retrieved from: https://plato.stanford.edu/archives/spr2018/entries/common-good/.

Rousseau, J.-J. (1997). The Social Contract and Other Later Political Writings. (V. Gourevitch, Transl.). Cambridge: Cambridge University Press.

Lee, S. (2020). Common Good. In Britannica Online Encyclopedia. Retrieved from: https://www.britannica.com/print/article/128312.

Locke, J. (1988). Two Treatises of Government. Cambridge: Cambridge University Press.

Manning, G. Curtis, K. (2003). The Art of Leadership. Boston, MA: McGraw-Hill.

Mansbridge, J. (2013). Common Good. In The International Encyclopedia of Ethics, Volume II (pp. 913-926). (H. LaFollette, Edit.). Malden, MA: Blackwell Publishing.

Mayana, E. (2013). Strengthening Ethical Political Leadership for Sustainable Peace and Social Justice in Africa: Uganda as a Case Study. In African Journal on Conflict Resolutions (pp. 113-146). 13(2).

Nwozor, A. (2014). Political Leadership, Poverty and the Failed State Syndrome in Africa. In Politics and Law in Africa (pp. 150-173). (Aloysius-Michaels Okolie, Onyemaechi A Eke, Paul A Areo, Edit.). Abakaliki, Nigeria: WillyRose \& Appleseed.

Plato. Republic. (1941). (F. M. Cornford, Trans.). Oxford: Oxford University Press.

Pontifical Council for Justice and Peace. (2005). In Compendium of the Social Doctrine of the Church. Nairobi. Kenya: Pauline Publications Africa.

Uchendu, E. Okpoko, P. U. \& Anugwom, E. (2010). Introduction: Discourse on African Leadership. In Perspectives on Leadership in Africa, Anugwom (pp. 1-15). Nsukka: Afro-Orbis Publishers.

Ukaegbu, C. C. (2010). Development Lag and the Imperative of Transformational Leadership in Sub-Saharan Africa. In Perspectives on Leadership in Africa (pp. 16-48). (Uchendu, E. Okpoko, P. U. \& Anugwom, E., Edit.). Nsukka: Afro-Orbis Publishers.

Constitution of Ukraine. (1996). Retrieved from: http://extwprlegs1.fao.org/docs/pdf/ukr127467E.pdf.

US Constitution. (2020). Retrieved from: https://www.law.cornell.edu/constitution/index.html. 